\title{
Joost Pauwelyn, Ramses A. Wessel and Jan Wouters (Eds.). 2012. Informal international lawmaking. (Oxford: Oxford University Press)
}

\author{
Oliver Westerwinter
}

Published online: 24 October 2014

(C) Springer Science+Business Media New York 2014

Research on international cooperation has made substantial progress by taking seriously the formal details of international institutions, such as international organizations (IOs) and treaties (Goldstein et al. 2000; Koremenos et al. 2001; Hawkins et al. 2006; Thomson et al. 2006). Formal rules do not, however, exhaust the institutional variety of international cooperation. They are often inadequate descriptions of the game that actors play in world politics (Achen 2006; Stone 2011, 2013). As Stone (2011) argues, IOs are governed by both formal and informal rules, and powerful states exploit informal governance to manipulate IO policies when their interests are acutely affected. For example, the rules of the game played in the World Trade Organization depart substantially from the formal treaty provisions (Steinberg 2002). Likewise, in the European Union (EU) the legislative co-decision procedure between the European Parliament and the Council of Ministers consists of an ensemble of formal and informal procedures that interact with one another in multiple ways to shape the interactions of member states and EU institutions (Kleine 2013). As these examples indicate, while formal rules are important features of contemporary global governance, in many situations informal practices may override, substitute for, or complement the formal provisions.

Most of the recent works on informal governance in international relations focus on informality within formal IOs (Stone 2011; Kleine 2013; Kilby 2013). However, as the volume Informal International Lawmaking edited by Joost Pauwelyn, Ramses Wessel, and Jan Wouters convincingly describes, the phenomenon is broader than this. The contributions to the volume cover a broad range of over 30 cases $^{1}$ of informal international cooperation ranging from informal procedures within IOs to informal groups of states and transnational networks of government bureaucrats. These contributions develop innovative theoretical arguments about the emergence, operation, and

\footnotetext{
${ }^{1}$ See Ayelet Berman, Sanderijn Duquet, Joost Pauwelyn, Ramses A. Wessel and Jan Wouters (Eds.). 2012. Informal international lawmaking: Case studies. Torkel Opsahl Academic EPublisher: The Hague, http:// www.fichl.org/fileadmin/fichl/documents/LOTFS/LOTFS_3_Web.pdf, accessed October 03, 2014.

O. Westerwinter $(\square)$

University of St. Gallen, St. Gallen, Switzerland

e-mail: oliver.westerwinter@unisg.ch
} 
consequences of informal modes of international cooperation; discuss the location of such informal modes within the "universe of law"; investigate how informal modes of cooperation interact with formal international law; assess the legitimacy and democratic accountability of informal modes of cooperation; and analyze how informal modes of cooperation are elaborated and implemented by domestic institutions. The volume concludes with a chapter that summarizes the contributions of the other chapters, outlines areas for future research, and articulates practical guidelines for negotiators and actors who are involved in the elaboration of informal international law.

Informal International Lawmaking is an important contribution to the study of international cooperation. It is theoretically and empirically the most comprehensive treatment of the topic of informal governance from the perspective of international law. The volume is, however, not without its limits. In the following, I discuss a few points with respect to which I see room for further improvement building upon the works edited by Pauwelyn, Wessel and Wouters. First, I discuss their decision to focus on state-based forms of informal international law. Second, I examine how the analyses in the volume approach the role of power in informal international lawmaking. Third, I comment on the volume's evaluation of the legitimacy- and accountability-enhancing potential of non-traditional forms of international lawmaking.

The volume sets out to draw attention to informal international lawmaking as an omnipresent phenomenon in global governance. In particular, it seeks to explain why informal international law is on the rise; what its standing is in the context of international law and how it relates to formal international law; and what its legitimacy and accountability challenges are (p. 1). In order to prepare the analytical ground for addressing these questions, the conceptual framework chapter by Joost Pauwelyn defines informal international law in contrast to traditional international law as "informal in the sense that it dispenses with certain formalities traditionally linked to international law. These formalities may have to do with output, process, or the actors involved" (p. 15). International law may be informal because it does not lead to formal treaties and agreements but rather to guidelines, standards, and other instruments of informal policy coordination (output). Furthermore, it may be informal in the sense that it occurs in loosely organized networks instead of formal IOs (process). Finally, it may be informal because it involves, in addition to traditional diplomatic actors such as heads of state or foreign ministers, other ministries, domestic regulatory agencies, or sub-federal entities (actors).

This definition of informal international law is useful because it allows scholars to examine informal governance within and beyond formal IOs, and to compare different forms of informal cooperation with each other. It also emphasizes that international cooperation can be informal in different ways and to different degrees. Yet, it also encounters an important limitation. Specifically, it remains largely focused on the activities of government actors (Pauwelyn, p. 19, Benvenisti, p. 299). As a consequence, the analyses in the volume tend to underemphasize the importance of non-state actors, such as multinational corporations and non-governmental organizations (NGOs), and exclude altogether private cooperation that does not involve state actors (Pauwelyn, p. 19). By downplaying the role of private actors and private forms of cooperation, the volume risks to truncate the dependent variable of interest; namely, the variety of forms of international cooperation. When it comes to governing a global policy problem and structuring their interactions with other actors within the 
international system, states can choose from a broad set of institutional forms, including formal international law based on treaties and IOs, informal international organizations, and transnational public-private governance schemes in which states cooperate with business actors and NGOs. They can even decide to take a back seat in the regulatory process and delegate regulatory tasks to entirely private governance schemes (Abbott and Snidal 2009; Lake 2010). If we seek to better understand what drives states' choices among these different institutional forms, we need to take into account the full spectrum of global governance arrangements and examine the strategic interactions among states and transnational actors that bring about specific cooperation forums. To examine only a part of this diverse institutional spectrum, risks producing answers that are incomplete at best. Thus, future research may want to further broaden the analytical scope and also take into account forms of cooperation in which states are not the major actors.

Another topic touched upon in several chapters (e.g., Voigt chapter 4, Pollack and Schaffer chapter 11, Benvenisti chapter 13) is the role of power in informal international law. As summarized in the concluding chapter: "power continues to play a role ... New forms of cross-border cooperation will not neutralize power differences, although the emergence of new actors, both States and non-State entities, implies a more competitive environment where power is increasingly dispersed and mutually checked" (pp. 519-520). While the acknowledgement of the role of power in informal international law is a valuable addition to the early functionalist studies of informal cooperation (Aust 1986; Lipson 1991; Abbott and Snidal 2000) and in line with the recent research on informal governance in international relations (Stone 2011, 2013), the concept of power remains under-theorized in the volume. Many of the contributions simply refer to "strong actors," such as the United States and the European Union, and "weak actors," such as small states (e.g., Pollack and Schaffer, p. 242, Benvenisti, p. 307, Pauwelyn et al., p. 520). There is, however, only scant discussion of what makes these actors powerful in the first place and how they use their power to shape the dynamics and outcomes of informal cooperation.

Such a treatment of power risks overlooking important questions related to the sources and functioning of power in informal governance. While materially powerful actors, such as the United States, can certainly be powerful players under informal governance (Stone 2011), material capabilities are not the only source of power. Consider, for example, power based on positions in informal governance networks (Avant and Westerwinter 2014). Given that informal governance arrangements often deal with complex policy problems in uncertain environments, information and knowledge are key for effective governance. Information is, however, hardly equally distributed among the actors involved in governing. Since formal procedures for the production and dissemination of policy-relevant information are typically sparsely developed or absent in informal cooperation forums, actors that occupy central positions in informal communication networks are likely to have privileged access to information which in turn allows them to shape outcomes in accordance with their particularistic interests (Avant and Westerwinter 2014). While power based on network positions can be used by the already powerful to further improve their bargaining position, it can also serve as a means of empowering otherwise weak players, such as small states and NGOs (Westerwinter 2013, 2014). Thus, informal governance does not necessarily only benefit strong players, but may also be used by the otherwise weak to obtain more 
favorable outcomes (Pollack and Schaffer, pp. 264-265). In short, while power indisputably continues to be important under informal governance, more theoretical and empirical research needs to be done on what constitutes power in the context of informal cooperation and how informality affects the power configuration among the actors involved in global governance.

Finally, several of the contributions to the volume examine the legitimacy and democratic accountability of informal international law (e.g., Klabbers chapter 10, Benvenisti chapter 13, Corthaut et al. chapter 14, Schepel chapter 16, Casini chapter 18). The major concern in these chapters is that informal forms of cooperation may circumvent the formal strictures of traditional international law as well as the domestic formalities linked to international lawmaking (pp. 512-513). Based on the individual contributions, the final chapter by Pauwelyn, Wessel and Wouters provides a balanced discussion of the accountability mechanisms of both formal and informal international law and comes to the conclusion that state consent — one of the key legitimacy sources of traditional international law - is no longer always sufficient for legitimate international cooperation and that cooperation outside state consensus can be legitimate (pp. 510-512). The authors suggest that "thick stakeholder consensus" may help to ensure the legitimacy and democratic accountability of informal international law. Thick stakeholder consensus refers to a practice of decision-making through inclusive, transparent, and predictable processes which include diverse and knowledgeable actors that has been emerging in informal international cooperation forums (p. 524). The authors even go one step further and suggest that in the future, thick stakeholder consensus may become the benchmark for all international law, including traditional formal international law (p. 534).

The argument that the practice of thick stakeholder consensus can help to solve the legitimacy and accountability problems of informal international law is not unproblematic. In particular, it is based on a too optimistic assessment of the decision-making and negotiation practices in informal governance arrangements. Negotiations in informal cooperation forums are by no means inclusive, transparent, and predictable per se, and outputs are not necessarily more carefully elaborated as compared to the outputs of formal intergovernmental forums. The Kimberley Process on the regulation of "conflict diamonds," which is part of the sample of cases which the volume examines, provides an example. The Kimberley Process is a prime example of informal international lawmaking as defined in this volume. It is an informal network constituted by governments, the diamond industry, and human rights NGOs that adopts standards for the global trade in rough diamonds with the aim of preventing "conflict diamonds" from fueling civil wars in Africa. While in principle all actors with a stake in the regulation of the global diamond business can become involved in the work of the Kimberley Process, in reality, access to negotiations and influence over outcomes are skewed toward those actors that have access to policy-relevant information (Westerwinter 2014). Outcomes are the result of hard and prolonged bargaining and are often difficult to predict, as illustrated by the negotiations over the Kimberley Process compliance of Zimbabwe between 2009 and 2011 (Westerwinter 2014). The result: an informal governance arrangement that is inclusive on paper and based on multi-stakeholder negotiations, but that in practice is dominated by a few powerful players with privileged access to information. Therefore, thick stakeholder consensus as a potential solution to the legitimacy and accountability challenges of informal international law 
should be treated more carefully. Specifically, it is likely that the positive legitimacy and accountability potential of thick stakeholder consensus can only be realized if certain conditions with respect to the institutional design of informal governance arrangements, such as transparency or equal access to information, are met. More theoretical and empirical research is needed on how the institutional design of informal governance arrangements affects their internal functioning and, thereby, their legitimacy and democratic accountability.

These limitations notwithstanding, Informal International Lawmaking provides valuable insights into the complexities of informal governance in world affairs and draws attention to aspects of informal cooperation that have remained underemphasized in existing research in the fields of international law and international relations. It is a book that all students of informal global governance should read and engage with.

\section{References}

Abbott, K. W., \& Snidal, D. (2000). Hard and soft law in international governance. International Organization, 54(3), 421-456.

Abbott, K. W., \& Snidal, D. (2009). The governance triangle: Regulatory standards institutions and the shadow of the state. In W. Mattli \& N. Woods (Eds.), The politics of global regulation (pp. 44-88). Princeton: Princeton University Press.

Achen, C. H. (2006). Evaluating political decision-making models. In R. Thomson, F. N. Stokman, C. H. Achen, \& T. König (Eds.), The European Union decides (pp. 264-298). Cambridge: Cambridge University Press.

Aust, A. (1986). The theory and practice of informal international instruments. International and Comparative Law Quarterly, 35(4), 787-812.

Avant, D., \& Westerwinter, O. (2014). The new power politics: Networks and transnational security governance. Manuscript: University of Denver.

Goldstein, J., Kahler, M., Keohane, R. O., \& Slaughter, A. M. (2000). Introduction: Legalization and world politics. International Organization, 54(3), 385-399.

Hawkins, D. G., Lake, D. A., Nielson, D. L., \& Tierney, M. J. (Eds.). (2006). Delegation and agency in international organizations. Cambridge: Cambridge University Press.

Kilby, C. (2013). An empirical assessment of informal influence in the World Bank. Economic Development and Cultural Change, 61(2), 431-464.

Kleine, M. (2013). Informal governance in the European Union. How governments make international organizations work. Ithaca: Cornell University Press.

Koremenos, B., Lipson, C., \& Snidal, D. (2001). The rational design of international institutions. International Organization, 55(4), 761-799.

Lake, D. A. (2010). Rightful rules: Authority, order, and the foundations of global governance. International Studies Quarterly, 54(3), 587-613.

Lipson, C. (1991). Why are some international agreements informal. International Organization, 45(4), 495538.

Steinberg, R. H. (2002). In the shadow of law or power? Consensus-based bargaining and outcomes in the GATT/WTO. International Organization, 56(2), 339-374.

Stone, R. W. (2011). Controlling institutions. International organizations and the global economy. Cambridge: Cambridge University Press.

Stone, R. W. (2013). Informal governance in international organization: Introduction to the special issue." Review of International Organizations, 8(2), 121-136.

Thomson, R., Stokman, F. N., Achen, C. H., \& König, T. (Eds.). (2006). The European Union decides. Cambridge: Cambridge University Press.

Westerwinter, O. (2013). Formal and informal governance in the United Nations Peacebuilding Commission. In A. P. Jakobi \& K. D. Wolf (Eds.), The transnational governance of violence and crime. Non-state actors in security (pp. 61-83). Houndmills, Basingstoke, Hampshire, UK: Palgrave.

Westerwinter, O. (2014). The politics of transnational institutions: Power, bargaining and institutional choice. Dissertation manuscript: European University Institute. 